\title{
The 'space problem' in the emplacement of granite
}

The space problem in granite emplacement has received an increasing amount of attention in recent years, particularly with the application of structural geology techniques and measurements of magnetic fabrics in plutons. of the classical emplacement mechanisms, cauldron subsidence and stoping have received little challenge. Diapiric emplacement and ballooning (in-situ inflation at the emplacement site) may generate similar structural effects and there is potential for confusion. Diapirism as a mechanism of transport and ascent of granitic magmas has been seriously questioned and alternative hypothesies, involving dyking ascent, are well developed. Pluton emplacement models involving dilation along major faults and shear zones are now being widely applied particularly in transcurrent and extensional settings. Emplacement in active contractional structures has been documented in a small number of cases. In terms of general models there is an increasing belief that granitic magma can be emplaced in a great variety of ways, and that this reflects a set of complexly interlinked, and as yet not fully understood, controls. A single, simple underlying theme may be that granite is fundamentally syntectonic and occurs mainly in convergent orogenic settings. As a fluid it will contribute to, and become part of, the regional (effective) stress in the orogen. This suggests that in the weak lower crust much of the strain of emplacement is, like the fluid pressure itself, shared regionally, i.e. the space problem is regionally solved. In the mid crust rheological and structural heterogeneities may strongly modify, but will not fundamentally alter, this situation.

\section{Introduction}

The 'Space Problem' or 'Room Problem' in granite geology was first clearly recognised and written about in 1835 when Charles Lyell recorded a debate he had been involved in with the Norwegian geologist Baltazar Keilhau concerning the Drammen granite near Oslo (Pitcher, 1993). Simply put, the 'Space Problem' is this: vast amounts of granite occupy the Earth's crust - how was the space for these granites created? To be more precise we do not understand the physical mechanism(s) by which space or room is created for granite. It would seem that by failing to understand such an apparently simple geological process, which is widespread throughout the geological record, we are failing to understand something fundamental and perhaps simple, about the nature of granite and the nature of continental crust accretion. The simplest, and one of the earliest general solutions to the space problem lies in the 'granitisation' or 'transformist' view of granites. This model, which was at its most popular in the middle of this century, stated that whole granite bodies were formed by the in-situ melting or metasomatic transformation of preexisting crustal rocks. Thus the country rocks were simply replaced by granite on a one-to-one volume basis. The space problem was simply solved. This is not now generally accepted because amongst other reasons, granites typically have a metamorphic aureole in the surrounding country rocks indicating that they are energetically (thermally) out of harmony with their surroundings and have therefore moved into place, i.e. they are allochthonous or intrusive. The modern general view of granite (as reflected in this group of papers) is that it forms in a source region associated with some kind of melting process, the melt is then segregated from the non-melted residuum, collects into a body or bodies and then ascends through the crust to a final site where it is emplaced. Thus it is because the vast majority of granites are allochthonous or are emplaced at sites separated from their sources that there is a room problem to be solved. Historically the various alternatives to the transformist/ replacement view were offered, like the view itself, as 'general solutions' to the problem. None were, although all had something to offer, and they might be more properly described as "partial solutions'. In what follows I will describe these classical partial solutions to the space problem and then look at more modern developments. In the final section we will look at how these specific emplacement processes might combine 'in time and space' to produce the phenomenon we observe, and we will also examine the possibility that there really is a simple single underlying process which generally solves the 'space problem'.

\section{The effect of the free surface: cauldron subsidence, ring dykes and cone sheets}

The Earth's surface is a surface of zero shear stress and a surface of stress relief. This basically means that:

1 stresses will be resolved parallel and perpendicular to the Earth's surface, and

2 the surface itself may be displaced vertically to allow space to be created immediately below.

These physical principles were utilised in the semi-quantative and quantative models of Anderson (1936) and Roberts (1970) (amongst others) for the emplacement of granitic bodies at high levels in the crust. In all these models, a precursor 'high level magma chamber' is envisaged, although its origin and emplacement mechanism is rarely, if ever, discussed. In any case an excess of magma pressure in this chamber causes the uplift of the free surface by a series of concentric inwardly dipping conical fracture surfaces which fill with magma released from the magma chamber beneath. These are the cone sheets. The evacuation of material from the underlying magma chamber creates a tendency for the overlying rocks to collapse and a series of outwardly dipping fractures form which the magma fills. These are the ring dykes and are typically flat topped with steeply outwardly inclined sides. Repeated intrusion by batches of different composition followed by erosion gives the classic centred complex. At the very highest levels in the crust the collapse of the central block may give rise to a surface caldera.

Cauldron subsidence is a well-accepted model of intrusion, and there are a small number of classic cases where the three-dimensional shape of the ring dykes appears to be verified (e.g.. Bussell, 1988). The emplacement style is restricted to within a few kilometres of the Earth's surface (our own studies suggest about $4 \mathrm{~km}$ ), 
since it is the effect of this free surface which dictates the fracture geometries. There are however cases of centred complexes formed by this mechanism at depths much greater than this: for example, the Rosses Granite in Donegal, NW Ireland (Pitcher and Berger, 1972). A possible reason for this is that these bodies are connected to the free surface by older fault systems.

\section{Stoping}

Locally derived, angular country rock xenoliths are common in granites, particularly at high crustal levels, and they maly reach tens or even hundreds of metres in size. The idea of stoping is that the magma invades along fractures in the country rocks and due to stress amplification at the fracture tips, these propagate, open and eventually blocks of country rock become surrounded by magma. The blocks then subside into the magma chamber below and magma is displaced upwards into the vacated space. This process, repeated many times, allows the entire magma body to ascend upwards. There is no doubt that stoping, often on a spectacular scale, does occur. It is however unlikely to be a major method of pluton emplacement. There are a number of reasons for this. Firstly, as the angular blocks begin to fall into the magma chamber below. they will begin to rotate, and so will require more space to occupy than when in their original position. For major amounts of stoping to take place therefore, the size of the magma chamber must increase steadily downwards, otherwise the stoped, rotated blocks will simply interfere with each other, lock-up, and bring the whole process to a halt. Bodies with such shapes are not seen. The second problem concerns the fact that the increased surface area which the relatively cold, stoped blocks present to the magma will draw heat out of the magma, and for large amounts of stoping this process will ultimately cause the magma to freeze. These limitations indicate that stoping, although important, cannot be a process that can allow the ascent and emplacement of a magma body across a large proportion of the Earth's crust (as, for example, in Paterson and Fowler, 1993, figure 12). The process of stoping works best at high crustal levels where fracture systems, both old and contemporary, can open easily, and where the country rocks are brittle.

\section{Forceful emplacement: diapirs and balloons}

There is a well-defined group of granitic plutons, seen all over the world, which combine the following characteristics:

- circular to subcircular to elliptical in plan;

- around the pluton, pre-existing structures in the country rocks are deflected and distorted, and often contain, adjacent to the pluton, and concordant with its external contact, a strong steeply inclined deformation fabric;

- within the pluton, there is also a deformation fabric, steeply inclined, concordant and intensifying towards the country rock contact.

The inference is clear that these plutonic bodies have somehow forced the country rocks aside and in so doing have deformed themselves. How does this happen?

\section{Diapirism}

Diapirism is a well-known physical process wherein bodies of low density fluid set in a higher density fluid will be buoyant and rise, as subspherical shapes, vertically upwards. The general formulation of this is Stokes law:

$$
\mathrm{V}=\frac{\Delta \rho g \mathrm{r}^{2}}{\eta_{\mathrm{c}}}
$$

where $V$ is the upward velocity, $\Delta \rho$ is the density difference between the two media, $r$ is the radius of the sphere of lower density, $g$ is the acceleration due to gravity and $\eta_{c}$ is the viscosity of the country rock. Diapirism can be created in simple physical experiments, in centrifuges and it has been inferred for various other low density geological materials (salt diapirs, serpentine diapirs). Analogue experiments and numerical modelling have shown that as the body moves upwards through the ductile country rocks, these flow around it to produce strong flattening strains above the pluton: simple shear type strains with vertical stretching on the flanks of the body, and strong constrictional strains with vertical stretching in the tail, all associated with deformation foliations which are concordant with the outline of the body. Internal deformation fabrics could be produced in the pluton if it were sheared against the country rocks during ascent or if convective overturn were to occur in the pluton during ascent (Schmelling et al., 1988 ), although the mixing produced by the latter is difficult to reconcile with the common preservation of internal petrological zoning in bodies like this. A body which rises this way could eventually come to a halt (and hence be emplaced) cither because of continuing crystallisation, which will increase the density and decrealse the driving force or because the viscosity of the country rocks becomes too high.

Diapirism as a mechanism of both ascent and emplacement hats one serious drawback: whereas at lower crustal levels the country rocks are sufficiently hot and weak to allow the pluton to move easily upwards, at higher crustal levels this is much less likely to be the case and, if the country rock viscosity is to remain low, heat must be extracted from the pluton itself. It is argued (Marsh, 1982) that the extraction of heat from the body will cause it to crystallise and stop ascending before it reached the crustal levels up to which these bodies are typically seen. I will discuss diapirism further under the topic of 'ascent".

\section{Ballooning}

When geologists began to measure the strain associated with deformation fabrics in what they thought were "diapirs" in the 1970s and 1980s (Holder, 1979; Ramsay, 1989; Courrioux, 1987; Brun et al.. 1990), they found an interesting thing: the strains were uniformly of a pure flattening type. Assuming that the plutons were subspherical in three dimensions and that the foliation was also spherically disposed, the strain type implied that the body had expanded equally in all radial directions, like the strain on the skin of an expanding balloon. This confirmed the idea that magma bodies could expand in situ at the point of emplacement. In some cases it seemed clear that the strains increased towards the contacts between the individual pulses in these zoned bodies as well as towards the country rock contact and so it seemed likely that it was the accession and inflation of successive pulses that caused the deformation of earlier pulses as well as the country rocks. Batloons have been described from many parts of the world and seem well accepted as an emplacement phenomenon. Different types of balloons have been described, e.g. "pillow balloons" (Brun et al., 1990), in which the vertical dimension is less, and which may be distinguished by subhorizontal circumferential stretching lineations around the periphery, and balloons which expand preferentially in onc horizontal direction, producing horizontal transcurrent shearing of opposite sense on opposing sides. A problem which has received much discussion is: how may balloons and diapirs be distinguished? The word diapir comes from the Greek verb 'to pierce' (Petford, 1996). In kinematic terms this, to me, implies a single dominant movement direction of a pluton relative to the surrounding crust. A balloon does not have a single such movement direction, is associated with a fattening type strain everywhere, and should in principle be distinguishable from a diapir. As diapirs move past country rocks they also flatten them, but providing the country rocks examined are at or below the equatorial diameter of the body at its final emplacement level, the strains will not be purely oblate and should contain a steep stretching lineation. Further, if kinematic indicators are available these should show 'plutonup' shear sense. Even if diapirs balloon a bit at the emplacement level this steep stretching lineation should still be preserved. The 'grey area' that is likely to exist is between diapirs that have a large ballooning component and balloons that show a large component of unidirectional movement (often laterally) at the emplacement site. Of the number of candidate plutons that have been examined in some 


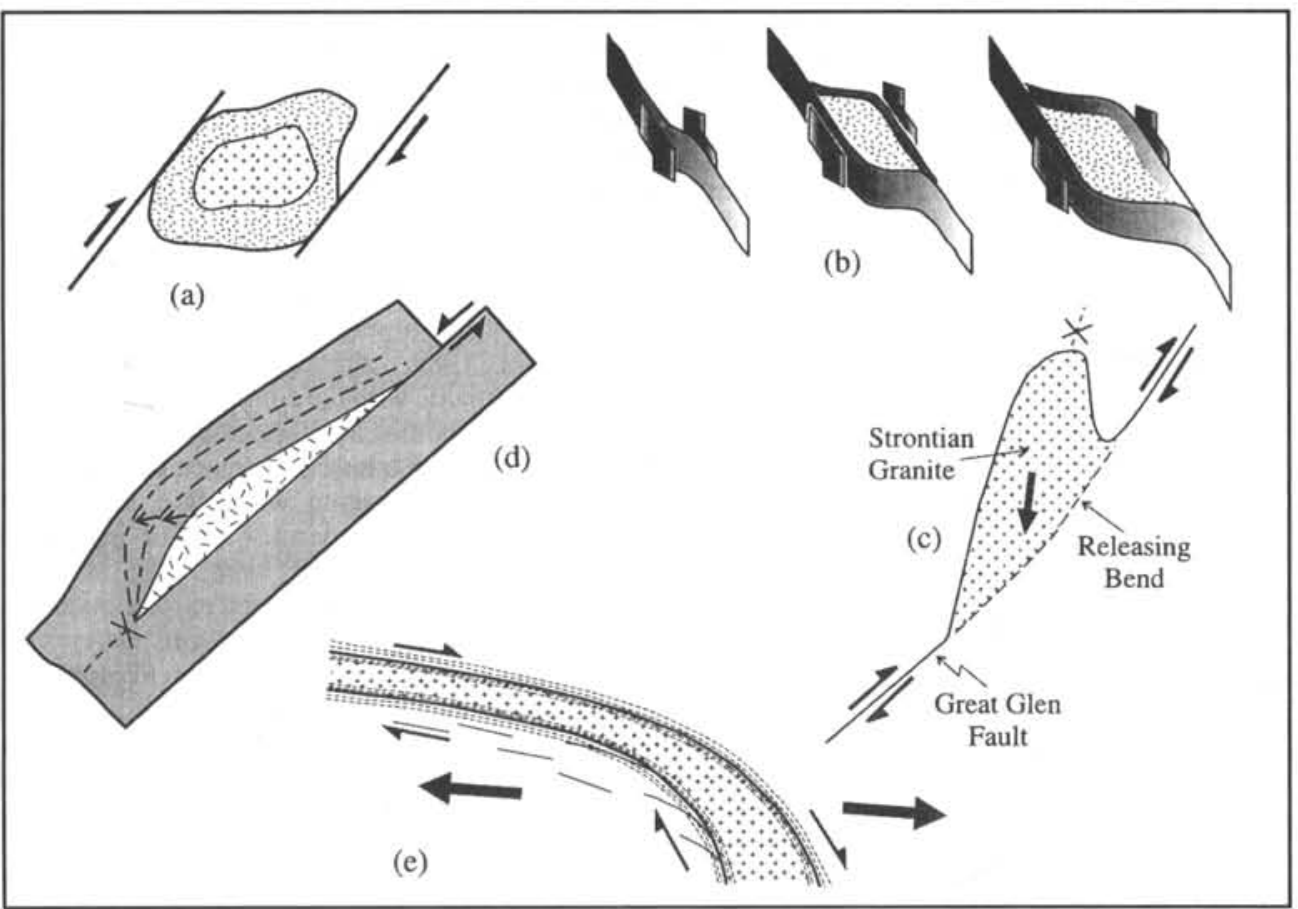

Figure 1 Some examples, drawn from the literature, of emplacement associated with tectonic structures.

a The Rehamma alkaline granite of Morocco located along the western Meseta shear zone (Adapted from Lagarde et al., 1990).

a The Mortagne pluton, France located along the south Armorican shear zone (Adapted from Guineberteau et al., 1987),

c The Strontian Granite, Scotland, adajacent to the Great Glen Fault (From Hutton, 1988a 1988b),

d The Main Donegal Granite, NW Ireland (From Hutton, 1982),

e Emplacement along an extensional shear zone (Quernetoq pluton, Hutton et al., 1990).

detail only Criffel (Courrioux, 1988), which shows steep strong stretching lineations in its tail, and Arran (England, 1992), which from the deflection of the country rocks must have moved dominantly upwards, provide the best cases of diapirism. Balloons, showing dominant flattening strains, appear more common; eg. Flamanville (Brun et al., 1990) and Ardara (Holder, 1979). Some authors (e.g. Schmelling et al., 1988) have shown that if the fabrics in diapirs are produced by internal convective overturn then the strains in the body can, depending on their location and the number of convective overturns achieved, be locally of flattening type, and therefore indistinguishable from the effects of ballooning. Once again the preservation of well-developed petrographic zonation within these sorts of bodies strongly argues against this process of convective overturn and mixing. It is much more likely that the deformation within plutons is produced by either inflation related to successive pulses (ballooning), or the viscous drag of the country rocks past the ascending pluton (diapirism), or their combination.

There has also been a problem about whether a balloon can expand and forcefully push aside its country rocks, and earlier magma pulses, if it is not fully crystallised, i.e. it is believed that an uncrystallised magma cannot push solid (albeit ductile) rocks out of the way, and therefore all diapirs and balloons ascend and emplace in the solid state. I have two examples which relate to this. The first is the Ardara Pluton in NW Donegal whose internal, concordant foliation is dominantly of magmatic state type (i.e. deformation before complete crystallisation) (Vernon and Paterson, 1993). The second example is the Arran granite in Scotland which has clearly pushed aside the country rocks yet it contains no visible macroscopic fabric at all. The only allowable conclusion is that the pluton emplaced itself while it was still fully liquid, pushing aside the country rocks, and only then did it crystallise (England, 1992). Finally, Paterson and others (Paterson and Fowler, 1993; Vernon and Paterson, 1993: Paterson and Vernon, 1995) have argued that many 'balloons' have not ballooned very much at all and owe most of their emplacement space to early stoping, followed by late-stage limited ballooning. They cite the Ardara pluton as a very good example of this. Recently, Molyneux and Hutton (unpublished) have remeasured the strain in and around this pluton and have found, in accord with the original authors (Holder, 1979) that there is an abundance of shortening strain in the rocks to account for the emplaced volume of this particular pluton by a ballooning mechanism.

\section{Emplacement associated with tectonic structures}

It is a very simple proposition that as major tectonic structures (faults and shear zones) develop, space is created within and around them into which granites may be emplaced. It has long been recognised that granites are often associated spatially with large tectonic structures: what has been demonstrated more recently is that there is often a demonstrable temporal connection between the emplacement of plutons and tectonic activity on the major structures. These types of granite emplacement models are therefore founded on the clear belief that such plutons are syntectonic. The development of these types of models followed the application of new techniques in structural geology through the 1970 s and 1980 s to the deformation features of granites and their envelopes. As well as foliation and lineation maps of granite fabrics, strain was determined using deformed xenoliths and mafic enclaves, centre-to-centre methods on crystal spacing, the orientation of folded and boudinaged veins within granites and from measurements of the Anisotropy of Magnetic Susceptibility (AMS). This was combined with determinations of shear sense from the wide variety of methods which became available during that period. A key aspect of these studies is the demonstration that the plutons are syntectonic with respect to the controlling major structures. This is usually achieved in two ways. Firstly it should be possible to demonstrate that the deformation fabric in the external shear zone (in the country rock) passes directly into the pluton, and that the fabric in the pluton is of magmatic state type (i.e. formed before complete crystallisation of the magma). It should also be possible to show that the lineation orientations and shear senses are the same between the country rocks and pluton. Folded granite veins associated with the deformation fabrics should also be expected in the external shear zone in the country rocks. Secondly, in a syntectonic granite the thermal aureole minerals should be synkinematic with respect to the shear zone deformation fabric in the country rocks. Once this temporal relationship has been established, the emplacement is modelled using fabric maps, strain distributions, shear sense and also taking account of the geometry of the external shear zone. Simple types of models include emplacement in pullaparts, at releasing bends, at fault terminations etc. In what follows I 
1. Al briefly look at a selection of these (there are now perhaps more tan $1(0)$ published accounts of plutons emplaced in this way), divided wo the three main categories of fault/shear zone types (Figure ().

\section{Transcurrent structures}

Some examples, among many others, include:

1 the simple 'pull-apart' type plutons between physically linked transcurrent shear zones, e.g. the Tobacco Root batholith of Schmidt et al. (1990), the Meissen pluton Germany (Mattern, 1996):

2 those sited at tensional zones between fault stepovers, e.g. some of the Moroccan plutons described by Lagarde et al. (1990), (Figure 1a), the Pombal pluton. NE Brazil (Archanjo et al., 1994);

3 emplatement at releasing bends, e.g. the Mortagne pluton of Guinebertealu et al. (1987), (Figure (b), the Doctors Flat Pluton, Australlia, (Morand, 1992);

4 emplacement at divergent bifurcating fault strands. e.g. the Mount Stuart batholith, Cascades (Miller and Paterson, 1992);

5 cmplacement at extensional terminations of transcurrent faults, e.g. the Strontian granite, Scotland, Hutlon (1988a; 1988b), (Figute lo):

6 emplacement in shear zones which have opened because of along-strike variations in shear zone displacement, e.g. the Main Donegal Granite (Hutton, 1982), (Figure Id)

7 emplacement in dilational areas associated with upright folds created by shear zones. e.g. the Ox Mountains granite, Ireland (McCaftiey, 1992).

$\therefore$ emplacement in large-scale vein-type geometries within shear zones (Castro, 1986).

\section{Extensional structures}

There are fewer examples of this type. The models typically contain inclined extensional shear zones or ramp-flat geometries which open during extensional movement. The classic example is the Quernetoy pluton in South Greenland (Hutton et al., 1990), (Figure le). Similar examples are seen in Greece (Koukoukevlas and Pe-Piper, 1991) and in the central Andes (5. cott et al., 1904! ?... orly units of the Struntian Pluton are ats. sociated with. . . llat extensional shear zonc geometry adjacent to a transcurrent shear zone termination (Hutton, 1988a. b).

\section{Thrust and high-angle reverse faults}

The carliest unequivocal report of this is by Blumenfeld and Boucher (1988), where the thrust type shear sense is demonstrated, for magmatic-state concordant fabrics. in a gently inclined granite sheet emplaced along a regional thrust in the Massif Central. The most spectacular example of the phenomenon is the Great Tonalite Sill of SE Alaska and British Columbia, a $1000 \mathrm{~km}-10 \mathrm{ng}$ by $20 \mathrm{~km}-$ wide pluton emplaced syntectonically as a steeply inclined series of sheets within a high-angle reverse shear zone which marks the collisional interfate between two of the major superterranes in the North American Cordillera (Hutton and Ingram, fo91; Ingram and Hutton. 1994). The implications of emplacement in contractional space denying lectonic structures such as these will be discussed later. Before that we move to some general conclusions and a discussion about tectonic controlled emplacement (and ascent).

\section{General conclusions and discussion}

\section{Sheeted structure of granitic plutons}

It appeas that many plutons, emplaced in fauls/shear fones, have a fundamental sheet-like structure. This is particularly evident with those intruded in exicnsional shear zones the Greenland examples atre 10 s 10100 s of squale kilometres in area bul less than one kilo- metre thick). Internat multiple sheeting is also important, and may be spectacular, as in the Ox Mountains Granite. Ireland (McCaffrey, 1992), or cryptic, in which case it may be suspected by the presence of country rock 'raft-trains' (remnant roof septa) as in the Main Donegal Granite (Pitcher and Read, 1959; Hutton, 1992). The Great Tonalite Sill is also composed of multiple granite dykes sheeted into each other. In theory, dykes should lic at right angles to the minimum principle stress and parallel to the maximum principle stress. It seems clear that granite sheets emplaced along shear zones are oblique (often highly) to the inferred directions of the principle stresses. Hutton (1991) concluded that this was because the sheets were fundamentally controlled by the geometry and weakness of the shear zones rather than by the stress directions alone.

\section{Granitic ascent}

Diapiric uprise, driven by the density contrast between magma and country rock, has traditionally been regarded as the main mechanism of granitic ascent. Marsh (1982) and Mahonet al. (1988) have shown that this presents a thermal problem and that the diapir will lose its heat (transferred to the country rocks) before it escapes the lower to middle crust. A possible mechanism, by which the viscosity of the country rocks will remain low, is for successive diapirs to rise via the same ascent path through the crust, creating 'nested diapirs' (Paterson and Vernon, 1995). Weinberg and Podadchikov (1994, 1995) have suggested that diapirs could reach quite high levels in the crust (although not within ten kilometres of the surface) if the crust had a power law rheology which allowed it to become weaker because of the shear stresses imposed by the uprising pluton. Another alternative is ascent by dyking as is the case with basaltic magma. Clemens and Mawer (1992). Petford et al. (1993) and Petford (1996) have shown for higher viscosily granitic magmas that, provided the rate of supply of the magma is high enough to keep the ascent path hot and prevent freezing (this requires a minimum critical width of dyke to be achieved), then very rapid ascent rates can occur. There has been much debate of 'diapirism versus dyking' with Rubin (1993; 1995) pointing out difficulties in growing dykes, in the source, up to their critical widths. Recently. Weinberg (1996) has adopted an intermediate stance, and suggested that both mechanisms may operate. even for the same magma batch and that this is controlled by a variety of parameters including magma composition and viscosity, magma pressure, tectonic environment and crustal temperature gradients. Hutton (1991) suggested that dyking ascent would naturally take advantage of steep faults and shear zones. At the appropriate crustal level. where, for example, there was additional dilational space available, or where there was a major change in crustal rock type (rheology), the ascending dykes would begin to accumulate and sheet into each other, thus creating sheeted plutons. It may be therefore that dyking is the ascent mechanism associated with major faults and shear zones, whereas diapirs may favour more homogenous crust or. more likely. conduits created at the intersection points of major faults (Jacepues and Reavy, 1994).

\section{General emplacement scenarios}

The numerous studies of plutons emplaced in extensional segments of tectonic structures suggests that this is a genuinely new type of emplacement mechanism that can take its place alongside the more classical mechanisms of cauldron subsidence, stoping, diapirism and ballooning. One can argue (Hutton. 1988b) that the continentat crust is fundamentally a heterogencous material, full of major faults and weaknesses and that granite magmas will inevitably exploit these zones during their ascent and, when dilation along them occurs, during their emplacement. Lower crustal level diapirism can occur in combination with shear zone ascent and emplacement, and at the highest levels the deflection of the free surlace can create space at the upper extremities of faults. One of the main difficulties with such a seenario is that it relies heavily on dilation/extension in the continental crust. This may be at odds with the fact that the vast majority of granites occur in convergent orogenic belts, where the stresses are 


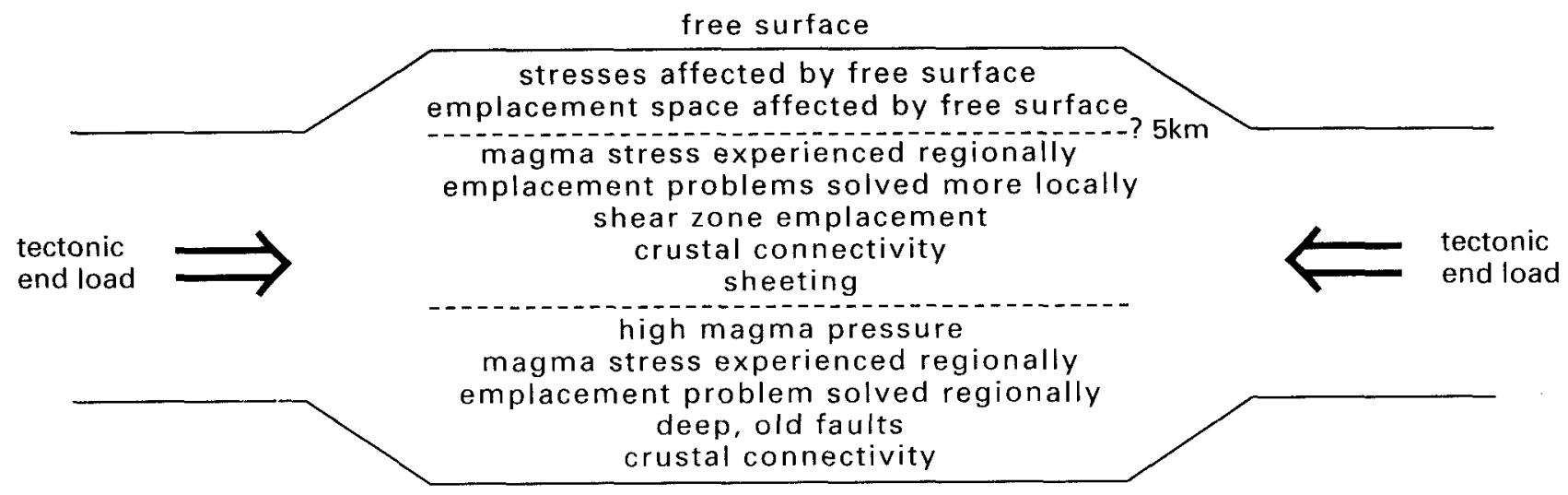

Figure 2 The space problem. Simplified summary of the main depth-defined realms of granite emplacement. See text for details.

compressional and the strains are contractional and in the general case 'space denying' with respect to granitic magma ascent and emplacement. The Great Tonalite Sill example is striking because it seems to show that magma can emplace itself in a space denying situation, along the interface between two colliding sub-plate-size continental fragments. The inference is clear (both from this and other examples of emplacement in thrusts and high-angle reverse faults): the magma pressure in these zones is higher than the tectonic compressional stress. This initiates a debate about two matters (Hutton, 1997). Firstly, is the bouyancy produced by the density contrast enough to overcome the tectonic compressional stress, and are other magma 'driving forces' available which can combine with the bouyancy to achieve this? The chief candidates (Hutton, 1997) are: the confining pressure in the source; the volume change on melting in the source; and the magma pressure aquired by the compaction, as a result of the hydrostatic stress and the tectonic compressional stress, of the restite around the melt pockets. The last of these is derived from the regional compressional stress itself with the implication that orogenic compression may significantly contribute to the magma pressure. Of the remainder, utilisation of the confining pressure 'head' and the stress produced by positive volume changes during melting relies on connections to lower stress areas higher in the crust and emphasises the additional importance of faults and shear zones in allowing this. Secondly, if the reality is that most granites do form, ascend and emplace themselves in orogenic situations in which the maximum principle stress is horizontal then simple analogue models may be applicable (Hutton, 1997). We are dealing with a deformable solid (the crust) containing bodies of fluid (uncrystallised magma/melt) all subject to a general stress in which the maximum principle stress is horizontal. Systems such as this are well known (for example in soil mechanics) and aspects of their behaviour can be described by the principle of effective stress $\sigma^{\prime}=\sigma-\mathbf{u}$, where $\dot{\sigma}^{\prime}$ is the effective principle stress, $\sigma$ is the total principle stress and $u$ is the pore fluid pressure). This basically means that in a system such as this the total stress is carried partly by the fluid in the pores (the fluid pressure) and partly by the contact forces between the solid parts (the effective stress), and that the fluid pressure acts to reduce the total imposed stress. A corollary of this is that the deformation in the system is produced only by the effective stress with the strain making no distinction between the stresses involved, it 'seeing' only their combination. Thus in the orogenic situation the magma pressure will be experienced as an indistinguishable part of the effective (regional) stress field. In terms of the space problem, if the country rocks are weak, as is the case in the lower crust, then it follows that the strains of emplacement (and ascent) associated with these magmatic bodies will be experienced regionally as well. Thus the space problem is, in the general case, regionally solved (Figure 2).

At higher levels in the middle crust we can expect far greater complexity in the regional stress field because of the lithological and structural variability found there. The magma pressure will still be distributed regionally although there will be far greater heterogeneity in the field than before. This will be reflected in the emplacemert styles of the plutons with the space problem being solved in a variety of ways according to local circumstances and particularly the oppoitunistic use of tensional and dilating sites in and around faults and shear zones. Despite these localised and variable solutions to the space problem, if the principle of effective stress holds then there should be a regional component to this accomodation: a prediction of the model which is testable. At still higher levels the dominant mode of space creation is by uplift and deformation of the free surface where cauldrons, stoping, doming/ballooning out of the high levels of faults and conduits (Jacques et al., 1997) and laccolithic inflation of sills associated with vertical feeders (Petford, 1996) are some of the main ways in which the space problem is solved.

\section{References}

Anderson, E M, 1936. The dynamics of the formation of cone sheets, ring dykes and cauldron subsidence: Proceedings of the Royal Society of Edinburgh, v. 56. pp. 128-163.

Archanjo, C J, Bouchez, J L, Corsini, M, and Vauchez, A., 1994. The Pombal granite pluton: magnetic fabric, emplacement and relationships with the Brasiliano strike-slip setting of NE Brazil (Paraiba State): Journal of Structural Geology. v. 16, pp.323-335.

Blumenfeld, P, and Bouchez. J L, 1988, Shear criteria in granite and migmatite deformed in the magmatic and solid state: Journal of Structural Geology, 10, pp.361-372.

Brun, J P, Gapais, D, Cogne, J P, Ledru, P, and Vigneresse, J L, 1990, The Flamanville Granite (northwest France): and uncquivocal example of a syntectonically expanding pluton: Geological Journal, v. 25, pp.271-286.

Bussell, M A., 1988, Structure and petrogenesis of a mixed magma ring dyke in the Peruvian Coastal Batholith: eruptions from a zoned magna chamber: Transactions of the Royal Society, Edinburgh: Earth Sciences, v. 79, pp.87-104.

Castro, A., 1986, Structural pattern and ascent model in the Central Extramadura batholith. Hercynian belt, Spain: Journal of Structural Geology. v. 8, pp. $633-645$.

Clemens. J D, and Mawer, C, 1992, Granite magma transport by fracture propagation: Tectonophysics, v, 204, pp.101-124.

Courrioux, G, 1987, Oblique diapirism: the Criffel granite/granodiorite zoned pluton (southwest Scotland): Journal of Structural Geology, v. 9, pp. $313-3.30$.

England, R W, 1992, The genesis, ascent and emplacement of the Northern Arran granite, Scotland: implications for granitic diapirism: Geological Society of America Bulletin, v. 104, pp.606-614.

Grocott, J, Brown, M, Dallmeyer, R D, Taylor, G K, and Treloar, R J, 1994, Mechanisms of continental growth in extensional arcs: and cxample from the Andean plate boundary zone: Geology, v. 22, pp.391-394.

Guineberteau, B, Bouchez, J I, and Vigneresse, J I, 1987. The Mortagne granite pluton (France) emplaced by pull-apart along a shear zone: Bulletin of the Geological Society of America, v. 99, pp.763-770.

Holder, M T, 1979, An emplacement mechanism for post-tectonic granites and its implications for their geochemical features, in Atherton, M P, and 
Tarney, J, eds., Origin of granite batholiths: geochemical evidence: Shiva Publishing, pp.116-128.

Hutton, D H W, 1982, A tectonic model for the emplacement of the Main Donegal Granite, NW Ireland: Journal of the Geological Society, v. 139, pp.615-631.

Hutton, D H W, 1988a, Igneous emplacement in a shear zone termination: the biotite granite at Strontian, Scotland: Geological Society of America, Bulletin, v, 100, pp.1392-1399.

Hutton, D H W, 1988b, Granite emplacement mechanisms and tectonic controls: inferences from deformation studies: Transactions of the Royal Society of Edinburgh: Earth Sciences, v. 79, pp.245-255.

Hutton, D H W, 1992, Granite sheeted complexes: evidence for the dyking ascent mechanism: Transactions of the Royal Society of Edinburgh: Earth Sciences, v. 83, pp.377-382.

Hutton, D H W, 1997, Syntectonic granites and the principle of effective stress: a general solution to the space problem? in Bouchez, J L, Hutton, D H W, and Stephens, W E, eds., Granite: from segregation of melt to emplacement fabrics; Kluwer Academic Publishers, Amsterdam. In press.

Hutton, D H W, Dempster, T J, Brown, P E, and Becker, S M, 1990, A new mechanism of granite emplacement: intrusion in active extensional shear zones: Nature, v. 343, pp.452-455.

Hutton, D H W, and Ingram, G, 1992, The Great Tonalite Sill of SE Alaska and British Columbia: emplacement into an active high-angle reverse shear zone: Transactions of the Royal Society of Edinburgh: Earth Sciences, v. 83, pp. 383-386.

Ingram, G, and Hutton, D H W, 1994. The Great Tonalite Sill: emplacement into a contractional shear zone and implications for Late Cretaceous to early Eocene tectonics in southeastern Alaska and British Columbia: Geological Society of America Bulletin, v. 106, pp.715-728.

Jacques, J M, and Reavy, R J, 1994, Caledonian plutonism and major lineaments in the SW Scottish Highlands: Journal of the Geological Society, v. 151, pp.955-970.

Jacques, J M, Hutton, D H W, and Reavy, R J, 1997, Crustal depth control of shear zones and deep lineaments in the Caledonian plutons of the SW Highlands of Scotland: Geological Magazine In press.

Koukoukevelas, I, and Pe-Piper, G, 1991, The Oligocene Xanthi pluton, northern Greece: a granodiorite emplaced during regional extension, Journal of the Geological Society, v. 148, pp.749-758.

Lagarde, J L, Omar, S A, and Roddaz, B, 1990, Structural characteristics of granitic plutons emplaced during weak regional deformation: examples from late Carboniferous plutons, Morocco: Journal of Structural Geology, v. 12, pp.805-821.

Mahon, K I., Harrison, T M, and Drew, D A, 1988, Ascent of a granitoid diapir in a tempreature varying medium: American Journal of Science, $v$. 282, pp.808-815.

Marsh, B D, 1982, On the mechanics of igneous diapirism, stoping and zone melting: American Journal of Science, v. 282, pp.808-855.

Mattern, F, 1996, The Elbe zone at Dresden-a late Paleozoic pull-apart intruded shear zone: Z. dt. geol. Ges. v. 147, pp.57-80.

McCaffrey, K, 1992, Igneous emplacement in a transpressive shear zone. Ox Mountains igneous complex: Journal of the Geological Society, v. 149. pp. 221-235

Miller, R B, and Paterson, S R, 1992, Tectonic implications of syn and post emplacement deformation of the Mount Stuart Batholith for mid-Cretaceous orogenesis in the North Cascades: Canadian Journal of Earth Sciences, v. 29, pp.479-485.

Morand, V, 1992, Pluton emplacement in a strike slip fault zone: the Doctors Flat Pluton, Victoria, Australia: Journal of Structural Geology, v. 14, pp. 205-213.

Paterson, S, and Fowler, T K, 1993, Re-examining pluton emplacement processes: Journal of Structural Geology, v. 15, pp.191-206.
Paterson, S R, and Vernon, R H, 1995, Bursting the bubble of ballooning plutons: a return to nested diapirs emplaced by multiple processes: Geological Society of America Bulletin, v. 107, pp.1356-1380.

Petford, N,1996, Dykes or diapirs?: Transactions of the Royal Society Edinburgh: Earth Sciences, v. 87, pp.104-114.

Petford, N, Ross, C K, and Kerr, J R, 1993, Dike transport of granitoid magmas: Geology, v. 21, pp.845-848.

Pitcher, W S, 1993. The nature and origin of granite: Blackie Academic and Professional, London, $321 \mathrm{pp}$.

Pitcher, W.S and Berger, A.R. 1972. The Geology of Donegal, A study of granite emplacement and unroofing. Wiley Interscience.

Pitcher, W S, and Read, H H, 1959, The main Donegal Granite: Quarterly Journal of the Geological Society, v. I14, pp.259-305,

Ramsay, J G, 1989, Emplacement kinematics of a granitic diapir: the Chindamora batholith, Zimbabwe: Journal of Structural Geology, v. 11, pp. 191-209.

Roberts, J L, 1970, The intrusion of magma into brittle rocks, in Newall,G and Rast, $\mathrm{N}$ eds., Mechanisms of Igneous Intrusion: Geological Journal Special Publication, no 2, pp.287-338.

Rubin, A M, 1993, Dikes vs diapirs in viscoelastic rock: Earth and Planetary Science Letters, v. 119, pp.641-659.

Rubin, A M, 1995, Getting granite dikes out of the source region: Journal of Geophysical Research, v, 100, pp.5911-5929.

Schmelling, H, Cruden, A R, and Marquart, G, 1988, Finite deformation in and around a fluid sphere moving through a viscous medium: implications for diapiric ascent: Tectonophysics, v. 149, pp.17-34.

Schmidt, C J, Smedes, H W, and O'Neill, J M, 1990, Syncompressional emplacement of the Boulder and Tobacco Root Batholiths (Montana USA) by pull-apart along old fault zones: Geological Journal, v. 25 , pp. 305-318.

Vernon, R, and Paterson, S, 1993, The Ardara Pluton, Ireland: deflating an expanded intrusion, Lithos, v. 31, pp. 17-32.

Weinberg, R F, 1996, Ascent mechanisms of felsic magmas: news and views: Transactions of the Royal Society of Edinburgh: Earth Sciences, v. 87. pp.95-103.

Weinberg, R F, and Podladchikov, Y Y, 1995, The rise of solid state diapirs: Journal of Structural Geology, v. 17, pp.1183-1195.

Donny Hutton is a reader in the Department of Geological Sciences at the University of Durham. He is a structural geologist who began his research on the deformation of midcrustal metasediments before moving to the emplacement and deformation of granite bodies. He has studied plutons in many parts of the world, including Donegal, Scotland. Iberia, Greenland, Alaska, Sierra Nevada, Brazil, China, and Italy. He has recently been appointed to the Chair of Earth Sciences at The Uni-

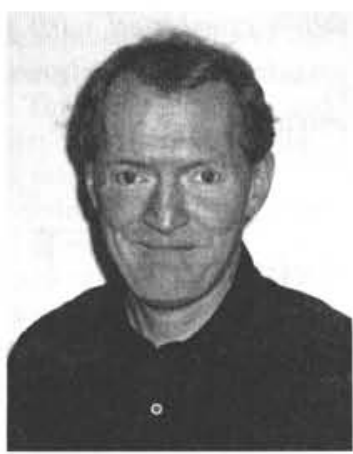
versity of Birmingham, UK. 